\title{
P53 in breast carcinoma: an immunohistochemical study
}

\author{
Zainab W. Aziz*, Shuaib H. Saleem ** \\ * Department of Pathology, Nineveh College of Medicine, ** Department of Pathology, College of \\ Medicine, University of Mosul.
}

(Ann. Coll. Med. Mosul 2011; 37 (1 \& 2): 34-41).

Received: $4^{\text {th }}$ Apr 2010; Accepted: $18^{\text {th }}$ May 2011.

\begin{abstract}
Objectives: The aims of the present study are; first, to find out the relative frequency of p53 overexpression in different types of breast cancer. Second, to correlate the p53 over-expression with different parameters, including the age and menopausal status of the patient, size, grade, stage, type of the tumor, and the status of axillary lymph nodes. Third, to compare our results with others

Methods: The study was both pro and retrospective and included 60 cases of breast carcinoma. Data were obtained from archives of the pathology department, at Al-jumhuri Teaching Hospital and collected in a period spanning from August 2008 to January 2009. P53 over-expression was assessed immunohistochemically .

Results: The patients ages ranged from 25 to 78 years (mean: 51.5 year); most of them were in the fourth decade $(41.2 \%)$. There was a significant inverse relation between p53 over-expression and the age of the patients $(p<0.001)$, in which the largest percentage of p53 positivity seen in the third decade. P53 over-expression was detected in 38.3\% of the cases. P53 over-expression was found in $(100 \%)$ of medullary carcinoma, $19 / 47(40.4 \%)$ of invasive ductal carcinoma (NOS), $1 / 3(33.3 \%)$ of ductal carcinoma in situ, and 1/6 (1.7\%) of invasive lobular carcinoma. P53 over-expression was not detected in mucinous and papillary carcinomas.

There was a significant direct correlation between $p 53$ over-expression and tumor size $(p=0.0274)$, grade $(p=0.032)$, and stage $(p<0.001)$.

There were no statistically significant relations between p53 over-expression and the menopausal status $(p=0.262)$ or axillary lymph node metastasis $(p=0.471)$.

Conclusions: Immunopositivity for p53 tumor suppressor protein was detected in $38.3 \%$ of the cases in this study. P53 over-expression was significantly correlated with patient's age, tumor grade, stage, and size, but no correlation was found with menopausal status and axillary lymph node metastasis.
\end{abstract}

Keywords: Breast carcinoma, P53 over-expression

الخلاصة

الأهداف: أجريت هذه الدراسة لتقبيم حالة الظهور المناعي لبروتين p53 في سرطان الثذي في مدينة الموصل و الربط بينها

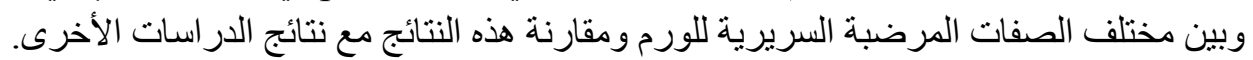

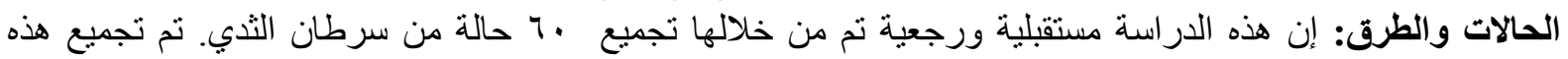

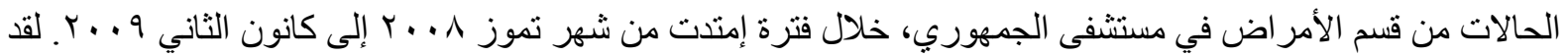
تم التحري عن بروتين p53 بطريقة مناعية-نسيجية_كيميائية.

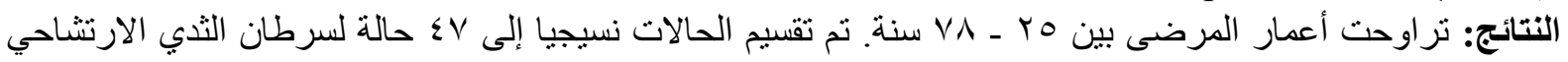

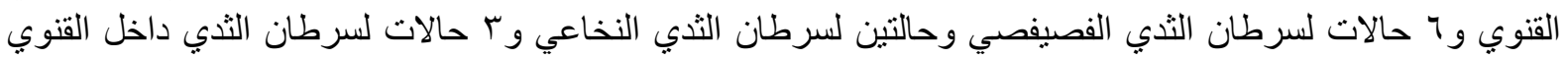
وحالة واحدة لسرطان الثدي المخاطيني . 


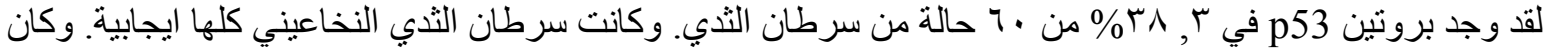

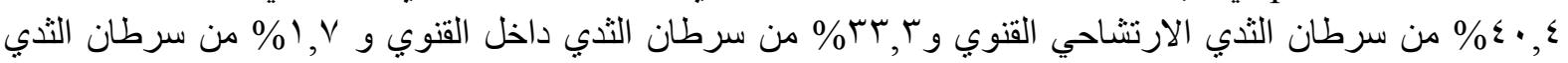

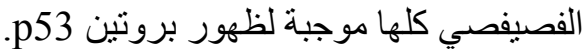

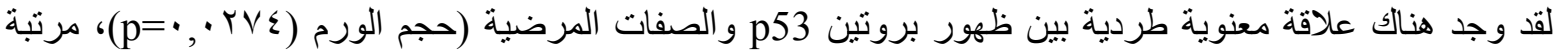

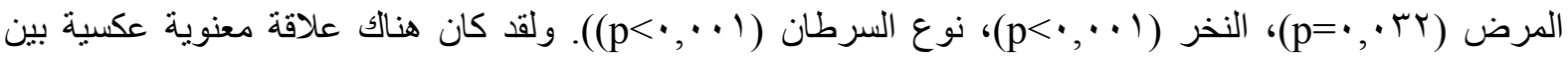

$$
\begin{aligned}
& \text { ظهور بروتين p53 و عمر المريضة. }
\end{aligned}
$$

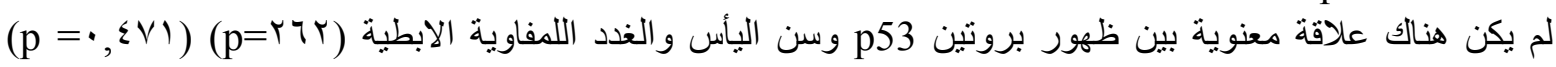

$$
\begin{aligned}
& \text { بالتعاقب. }
\end{aligned}
$$

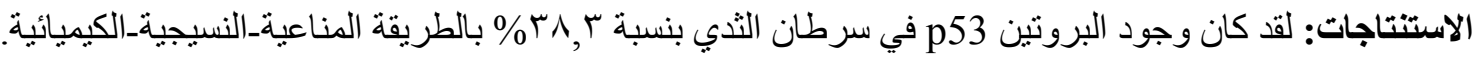

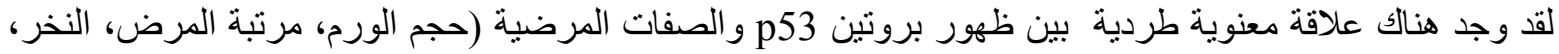

$$
\begin{aligned}
& \text { نوع السرطان). ولقد كان هناك علاقة معنوية عكسية بين ظهور بروتين p53 و عمر المريضة. لم يكن هناك علك علاقة معنوية } \\
& \text { بين ظهور بروتين p53 وسن اليأس و الغدد اللمفاوية الابطية . } \\
& \text { إن سرطان الثدي النخاعي كان أكثر ظهور اللبروتين p53 ، أما سرطان الثني الفصيفصي و المخاطيني فهما أقل ظهورا }
\end{aligned}
$$

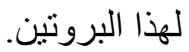

B

reast cancer is the most common type of cancer among women in both highresource and low-resource settings, and is responsible for over 1.3 million of the estimated 10 million neoplasms diagnosed worldwide each year in both sexes ${ }^{(1)}$. Since the p53 tumor suppressor gene has been found to be mutated in more than $50 \%$ of human cancers, it has attracted the interest of numerous researchers ${ }^{(1)}$. In breast cancer the reliability for detecting p53 mutations by $\mathrm{IHC}$ was found to be high enough with particular attention to the simplicity and costeffectiveness when compared to other techniques.

Several studies believe that it is important to investigate the correlation between p53 immunostaining with traditional factors, to predict the prognosis, drug responsiveness, and survival rate among patients with breast cancer ${ }^{(2)}$. In general p53 over-expression in breast cancer is in the range of $19 \%-40 \%{ }^{(2)}$

P53 is encoded by Tp53 gene, located at $17 \mathrm{p} 13$, this contains 11 exons spanning $20 \mathrm{~kb}$ $(2,3)$

There are 3 functional distinct regions in p53:

1- Acidic n-terminal region (codons 1-101).

2- Central DNA binding core region (codons 102-292).

3- Basic c-terminal region (codons 293393).
P53 acts as brakes to the cycle of cell growth, DNA replication and division into two new cells ${ }^{(3)}$, and preventing inappropriate cell proliferation and maintaining genome integrity following genotoxic stress ${ }^{(4)}$.

Our aims of the present study are: (1) finding out the relative frequency of P53 overexpression in different types of breast carcinoma. (2) correlating the P53 overexpression with different parameters including the age and the menopausal status of the patient, size, grade, stage, type of the tumor, and status of axillary lymph nodes. (3) comparing our results with others.

\section{Patients and Methods}

Patients: A pro and retrospective study was carried out in a series of sixty consecutive patients diagnosed with primary breast carcinoma. All patients had operable tumors with no evidences of distant dissemination at the time of diagnosis, and they underwent lumpectomy or modified radical mastectomy as well as axillary lymph node clearance. A representative tissue block of each case was chosen for IHC.

Clinicopathological data were obtained from archives of the department of pathology laboratory, at Aljumhuri Teaching Hospital, Mosul City and these included; 
Age (divided into six groups 21-30, 31-40, 41$50,51-60,61-70,71-80)$, menopausal status (divided into two groups $\leq 50$ and $>50$ years), tumor size in centimeters $(<2,2-5,>5)$; histological type which was evaluated according to the $\mathrm{WHO}$ classification. Tumor grade was assessed by using Nottingham modification of the Bloom Richardson Grading system and tumor stage by adopting the TNM system.

IHC staining: Tissue paraffin blocks were cut into sections of $4 \mu \mathrm{m}$ and mounted on silanized slides. The slides were left in the oven at $65^{\circ} \mathrm{C}$ overnight. Sections then deparaffinized and rehydrated by descending grades of ethanol and distilled water. The slides were immersed in preheated retrieval solution and the Coplin jars were put in water bath (95-99) ${ }^{\circ} \mathrm{C}$ for 30 minutes. Next, they were left to cool at room temperature for 20 minutes. Levamisole blocker was added, and slides were incubated for 20 minutes, and then rinsed with wash buffer. Slides were incubated with $100 \mu l$ primary antibody for 30 minutes, followed by rinsing with buffer. Slides were incubated with secondary antibody for 30 minutes in warm area, and then rinsed with wash buffer bath for 5 minutes followed by preparing working solution of $1 \mathrm{ml}$ of permanent red substrate buffer and substrate buffer solution with $+10 \mu l$ of permanent red chromogen solution and lastly were put in dark area. Two hundred $\mu$ l of this solution was added on each slide for 1015 minutes and then the slides were incubated for 15 minutes. The slides were rinsed with distilled water and bathed for 5 minutes, which was followed by another wash. Positive and negative control slides were involved in each run. Known positive breast carcinoma samples were used as positive control. For negative control the same protocol was followed with omission of the primary antibody and incubation with Tris Buffered saline (TBS).

IHC analysis: $\mathrm{H}$-score was used to indicate positivity of p53 nuclear staining. The intensity of immunostaining on each slide was rated on a four-point scale: 0 none; $1+$ light; 2+ moderate; $3+$ heavy; and $4+$ intense. The percentage of immunopositive tumor cells was determined by counting a minimum of 200 cells from at least three representative highpower fields. $\mathrm{H}$-scores were then calculated as the product of intensity ( 0 to 4$) X$ distribution ( $0 \%$ to $100 \%$ ), with $\mathrm{H}$-score ranging from 0 to 400. A cut-off value for the $\mathrm{H}$-score of $\geq 50$ was used to indicate p53 positivity.

Statistical analysis: The relationship between p53 over-expression and various clinicopathologic parameters was analyzed by Fisher Freeman Holtons' test. The results were considered statistically significant if the $p$ value was $\leq 0.05$.

\section{Results}

The patients' age range was 25-78 years (mean 51.5 year), most of them were in the fourth decade (41.2\%), however data concerning the age were missing in 9 patients. Forty four patients $(73.3 \%)$ were premenopausal and sixteen $(26.7 \%)$ were post menopausal.

The tumor size ranged from 1 to $10 \mathrm{~cm}$ (mean $4.2 \mathrm{~cm}$ ) most of the tumors $(61.6 \%)$ were T2. Histologically, there were 47 infiltrative ductal carcinoma (NOS) and 13 cases showing different patterns ( 6 invasive lobular, 3 DCIS, 2 medullary, 1 mucinous and 1 papillary).

Most of the cases of IDC were categorized as grade II (56.9\%); grade III and grade I formed $(37.2 \%)$ and $(5.9 \%)$ respectively. Thirty three cases $(55 \%)$ presented with axillary lymph node involvement by metastatic disease.

\section{Correlation between p53 over-expression} and the studied clinicopathological parameters: There was a significant correlation between p53 over-expression and the age of patients $(p<0.001)$ with largest percentage of p53 positivity seen in patients in the third decade, (Table 1). An increased relation was found between p53 positivity and the age of the patients.

There was no statistically significant relation between p53 over-expression and the menopausal status, $(p=0.262)$, (Table 2$)$.

P53 over-expression statistically had significant correlation with tumor size $(p=0.0274)$, as the largest proportion of p53 positivity occurred in T3 (53.3\%), (Table 3 ). 
Regarding tumor type (Table 4), P53 was positive in $100 \%$ of medullary carcinoma, in $40.4 \%$ of invasive ductal carcinoma (NOS), in $33.3 \%$ of ductal carcinoma in situ, in $1.7 \%$ of invasive lobular carcinoma and in $0 \%$ of mucinous and papillary carcinomas, (Fig 1-3).

Significant direct relation was found between p53 and tumor grade $(p=0.032), \quad p 53$ immunopositivity increased from $33.3 \%$ in grade I to $36.9 \%$ in grade III, (Table 5 ).
P53 over-expression failed to show a significant relation with axillary lymph node metastasis $(p=0.471)$, although $p 53$ was positive in $42.2 \%$ compared to $33.3 \%$ in tumors with no ALN metastasis, (Table 6).

There was a significant direct relationship between p53 over-expression and the tumor stage $(p<0.001)$, (Table 7$)$.

Table (1): P53 over-expression and patient's age.

\begin{tabular}{|c|c|c|c|c|c|c|c|}
\hline \multirow{2}{*}{ Age (year) } & \multicolumn{2}{|c|}{ Total } & \multicolumn{2}{|c|}{$+v e$} & \multicolumn{2}{|c|}{$-v e$} & \multirow{2}{*}{$\mathrm{p}$-value } \\
\hline & No. & $\%$ & No. & $\%$ & No. & $\%$ & \\
\hline $21-30$ & 4 & 7.8 & 0 & 0.0 & 4 & 13.3 & \multirow{6}{*}{$\begin{array}{c}<0.001 \\
\text { Significant }\end{array}$} \\
\hline $31-40$ & 10 & 19.6 & 7 & 33.3 & 3 & 10.0 & \\
\hline $41-50$ & 21 & 41.2 & 6 & 28.6 & 15 & 50.0 & \\
\hline $51-60$ & 4 & 7.8 & 2 & 9.5 & 2 & 6.7 & \\
\hline $61-70$ & 8 & 15.8 & 5 & 23.8 & 3 & 10.0 & \\
\hline $71-80$ & 4 & 7.8 & 1 & 4.8 & 3 & 10.0 & \\
\hline Total & 51 & 100 & 21 & 100 & 30 & 100 & \\
\hline
\end{tabular}

Table (2): P53 over-expression and menopausal status.

\begin{tabular}{|l|c|c|c|c|c|c|c|}
\hline \multirow{2}{*}{ Menopausal status } & \multicolumn{2}{|c|}{ Total } & \multicolumn{2}{c|}{+ +ve } & \multicolumn{2}{c|}{-ve } & \multirow{2}{*}{ p-value } \\
\cline { 2 - 7 } & No & $\%$ & No. & $\%$ & No. & $\%$ & \\
\hline Premenopausal $(\leq 50 \mathrm{yr})$ & 41 & 80.3 & 15 & 36.5 & 26 & 63.4 & 0.262 \\
\hline Postmenopausal $(>50 \mathrm{yr})$ & 10 & 19.6 & 5 & 50.0 & 5 & 50.0 & (NS) \\
\hline Total & 51 & 100 & 20 & 39.2 & 31 & 60.7 & \\
\hline
\end{tabular}

Table (3): P53 over-expression and tumor size.

\begin{tabular}{|l|c|c|c|c|c|c|c|}
\hline \multirow{2}{*}{ Tumor size $(\mathrm{cm})$} & \multicolumn{2}{|c|}{ Total } & \multicolumn{2}{c|}{ P53+ve } & \multicolumn{2}{c|}{ P53-ve } & \multirow{2}{*}{ p-value } \\
\cline { 2 - 8 } & No. & $\%$ & No. & $\%$ & No. & $\%$ & \\
\hline$<2$ & 8 & 13.3 & 2 & 25.0 & 6 & 75.0 & \multirow{2}{*}{0.0274} \\
\cline { 1 - 7 } & 37 & 61.7 & 13 & 35.1 & 24 & 64.9 & Significant \\
\hline$>5$ & 15 & 25 & 8 & 53.3 & 7 & 46.7 & \\
\hline Total & 60 & 100 & 23 & 38.3 & 37 & 61.7 & \\
\hline
\end{tabular}

Table (4): P53 over-expression and histological type of tumor.

\begin{tabular}{|l|c|c|c|c|c|c|c|}
\hline \multirow{2}{*}{ Histological type of tumor } & \multicolumn{2}{|c|}{ Total } & \multicolumn{2}{c|}{ P53+ve } & \multicolumn{2}{c|}{ P53-ve } & \multirow{2}{*}{ p-value } \\
\cline { 2 - 7 } & No. & $\%$ & No. & $\%$ & No. & $\%$ & \\
\hline IDC (NOS) & 47 & 78.3 & 19 & 40.4 & 28 & 59.6 & \\
\hline ILC & 6 & 10 & 1 & 1.7 & 5 & 83.3 & \\
\hline DCIS & 3 & 5 & 1 & 33.3 & 2 & 66.7 & \multirow{2}{*}{ Significant } \\
\hline Medullary & 2 & 3.3 & 2 & 100 & 0 & 0.0 & \\
\hline Mucinous & 1 & 1.6 & 0 & 0.0 & 1 & 100 & \\
\hline Papillary & 1 & 1.6 & 0 & 0.0 & 1 & 100 & \\
\hline Total & 60 & 100 & 23 & 38.3 & 37 & 61.7 & \\
\hline
\end{tabular}


Table (5): P53 over-expression and tumor grade.

\begin{tabular}{|l|c|c|c|c|c|c|c|}
\hline \multirow{2}{*}{ Grade } & \multicolumn{2}{|c|}{ Total } & \multicolumn{2}{c|}{$+\mathrm{ve}$} & \multicolumn{2}{c|}{-ve } & \multirow{2}{*}{ p-value } \\
\cline { 2 - 7 } & No. & $\%$ & No. & $\%$ & No. & $\%$ & \\
\hline I & 3 & 5.9 & 1 & 33.3 & 2 & 66.7 & \multirow{2}{*}{0.032} \\
\cline { 1 - 7 } II & 29 & 56.9 & 10 & 34.4 & 19 & 65.5 & \multirow{2}{*}{ Significant } \\
\hline III & 19 & 37.2 & 7 & 36.9 & 12 & 63.2 & \\
\hline Total & 51 & 100 & 18 & 35.3 & 33 & 64.7 & \\
\hline
\end{tabular}

Table (6): P53 over-expression and ALN.

\begin{tabular}{|l|c|c|c|c|c|c|c|}
\hline \multirow{2}{*}{ ALN involvement } & \multicolumn{2}{|c|}{ Total } & \multicolumn{2}{c|}{$+\mathrm{ve}$} & \multicolumn{2}{c|}{-ve } & \multirow{2}{*}{ p-value } \\
\cline { 2 - 8 } & No. & $\%$ & No. & $\%$ & No. & $\%$ & \\
\hline Yes & 33 & 55 & 14 & 42.4 & 19 & 57.6 & \multirow{2}{*}{0.471 (NS) } \\
\hline No & 27 & 45 & 9 & 33.3 & 18 & 66.7 & \\
\hline Total & 60 & 100 & 23 & 38.3 & 37 & 61.7 & \\
\hline
\end{tabular}

Table (7): P53 over-expression and stage of tumor.

\begin{tabular}{|c|c|c|c|c|c|c|c|}
\hline \multirow{2}{*}{ Stage } & \multicolumn{2}{|c|}{ Total } & \multicolumn{2}{|c|}{ P53+ve } & \multicolumn{2}{|c|}{ P53-ve } & \multirow[b]{2}{*}{$p$-value } \\
\hline & No. & $\%$ & No. & $\%$ & No. & $\%$ & \\
\hline Stage 1 & 1 & 1.6 & 0 & 0.0 & 1 & 100 & \multirow{6}{*}{$\begin{array}{c}<0.001 \\
\text { Significant }\end{array}$} \\
\hline Stage II A & 18 & 30 & 3 & 16.7 & 15 & 83.3 & \\
\hline Stage IIB & 10 & 16.6 & 6 & 60.0 & 4 & 40.0 & \\
\hline Stage IIIA & 15 & 25 & 6 & 40.0 & 9 & 60.0 & \\
\hline Stage IIIB & 9 & 15 & 4 & 44.4 & 5 & 56.6 & \\
\hline Stage IIIC & 7 & 11.6 & 4 & 57.1 & 3 & 42.9 & \\
\hline Total & 60 & 100 & 23 & 38.3 & 37 & 61.7 & \\
\hline
\end{tabular}
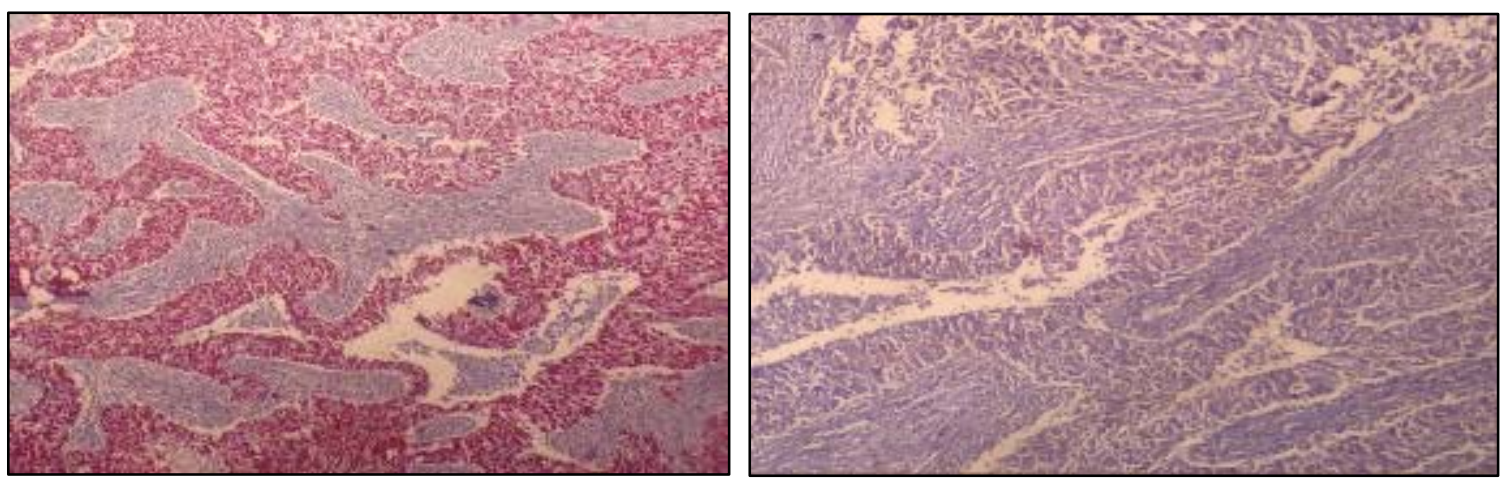

Figure (1): IHC staining for p53 (control) (x100), left positive; right negative.
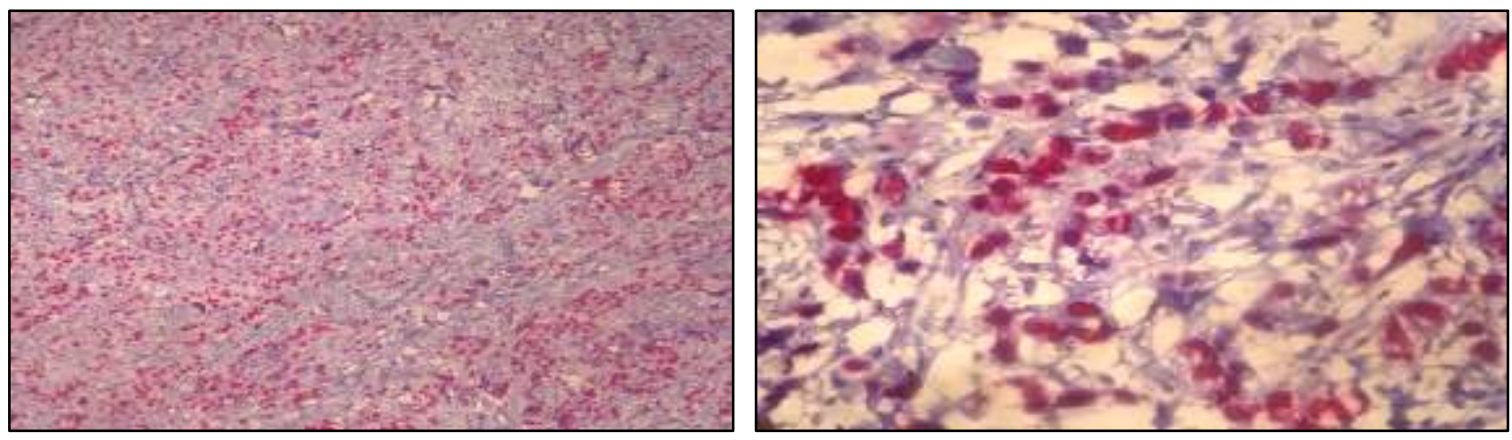

Figure (2): Infiltrative lobular carcinoma. Positive staining. Left, (x100); right, (x400), (H Score=270). 

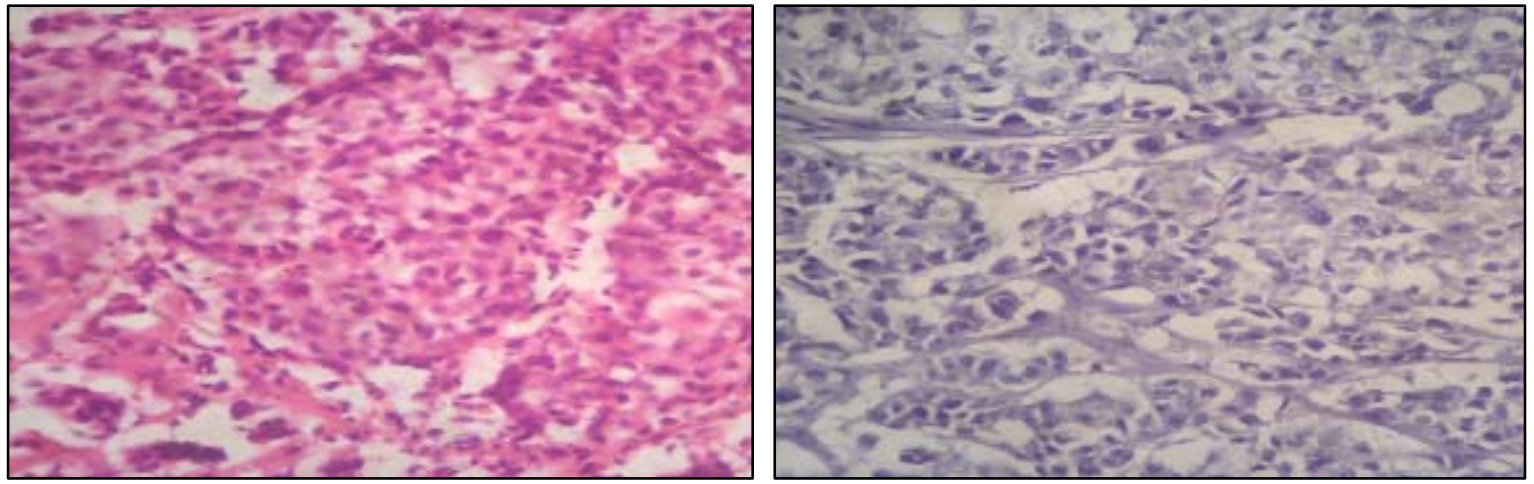

Figure (3): Infiltrative ductal carcinoma Grade III. Left, $H \& E(x 400)$; right, negative staining for p53 (x400).

\section{Discussion}

Among the biological markers investigated, p53 gene has received a considerable attention as a promising prognostic and predictive marker in breast cancer. P53 overexpression is believed to be an early stage in tumorigenesis, thus immunostaining to detect mutant p53 provides sufficiently reliable information for clinical decision making ${ }^{(5,6)}$. In the current study p53 immunostaining was positive in $38.3 \%$. However others reported different results $(7,8,9)$.

Our study showed a significant inverse correlation with increasing age $(p=0.001)$, with higher expression being found in younger patients and lower expression in older age group. This is comparable to the findings of most of other studies ${ }^{(10-13)}$, but different from Pich $\mathrm{A}^{(14)}$ and Levesque ${ }^{(15)}$ et al.

There was a tendency for occurrence of p53 immunopositive tumors in the premenopausal women although this did not achieve statistical significance $(34.1 \%$ premenopausal women versus $31.3 \%$ postmenopausal women). Similar results were obtained by others ${ }^{(16-19)}$. However, Uchikawa et al ${ }^{(20)}$ revealed a weak correlation with postmenopausal status.

The higher level of positive p53 immunostaining was detected in larger tumor size. These results were comparable with the data in the literature $(11,20,21)$.

In the current study, the strong positivity of p53 seen in medullary carcinomas and the low reading of p53 in lobular carcinoma are explained by the relation of $p 53$ with the grade of the tumor. Medullary carcinoma is always of high grade so high correlation with p53 while invasive lobular carcinomas are of low grade so weakly correlated with $\mathrm{p} 53$. These findings are comparable with those found by Mhjoub et al. On the other hand Iwaya and Eteebary in their study failed to show a particular predilection of p53 immunostaining to certain types of breast cancer.

The frequency of p53 mutation is directly correlated with the grade of the breast cancers i.e. higher expression is detected in higher grade $(10,11,13,22)$. This fact is also reflected in our study. Other people reported no significant correlation ${ }^{(14,23)}$.

We couldn't find a significant correlation between p53 and ALN metastasis and this is similar to most studies ${ }^{(10,14,15,17,22)}$.

Most of our cases were in stages II and III, the same as in other studies ${ }^{(23,24)}$ which are rather advanced for this type of tumor. We found a significant direct relation between p53 over-expression and tumor stage $(p<0.001)$, which is similar to those of Uchikawa and Mourao et al ${ }^{(24)}$.

\section{Conclusions}

The $38.3 \%$ p53 positivity in breast carcinoma was within the general range observed by others. P53 over-expression showed a significant correlation with the patient age, and size, grade and stage of tumor. However there was no significant correlation with ALN metastasis and menopausal status. P53 overexpression was positive in the two cases of medullary carcinoma, showed lower positivity in lobular carcinoma and was negative in mucinous and papillary carcinomas. Finally 
validity and simplicity of application of $\mathrm{IHC}$ technique in determining the status of p53 protein, as it was clearly noticed encourage its use as a prognostic factor.

\section{References}

1. Liv and Imaginis. Breast Cancer: Statistics on Incidence, Survival, and Screening. 2008; 2-12.

2. Etebary M, Jahanzad I, Azizi E et al. Immunohistochemical analysis of p53 and its correlation to the other prognostic factors in breast cancer. Acta Medica Iraninca; 2002; 40:2-5.

3. Vogelstein B, Lane D, Levine A.J, et al. The p53 network. Nature 2000; 408:307310.

4. Tommiska J. ATM, RAD50 and p53 in Breast Cancer. University of Helsinki 2007;1-18.

5. Gordon D. Breast health the natural way, the women natural health series. Chapter (10): Breast Cancer. Women Health, Natural Medicine 2003; Book series: 198207.

6. Turner B.C, Krajewski S, Krajewska M, et al. BAG-1: A Novel Biomarker Predicting Long-Term Survival in Early-Stage Breast Cancer. J. of Clin. Oncology; 2001; 19(4): 992-1000.

7. Gurkan A, Erdogan G, Erdogan O, et al. Expression of c-erbB-2 and p53 in Breast Carcinoma Patients: Comparison with Traditional Prognostic Factors and Survival. J. Intern. Med. Res. 2004; 32: 455- 464.

8. Tirgari F, Abdi Rad A, Mahjoub F, et al. Male Breast Carcinoma: An Immunohistochemical Study of 50 Cases from Iran. Iranian J. of Patho. 2008; 3(1): 94-99.

9. Yamashita $\mathrm{H}$, Nishio $M$, Toyama $T$, et al. Coexistence of HER2 over-expression and p53 protein accumulation is a strong prognostic molecular marker in breast cancer. B.C. R. 2004; 6(1):1-90.

10. Sierra $A$, Castellsague $X$, rtola $S$, et al. Apoptosis Loss and Bcl-2 Expression: Key Determinants of Lymph Node Metastases in T, Breast Cancer'. Clin. Ca. Res. 1996; 2:1887-1894.
11. Song H.S, Do $Y$, Kang S.H, et al. Prognostic Significance of Immunohistochemical Expression of p53 Gene Product in Operable Breast Cancer. Ca. Res. Treat. 2006; 38: 4-8.

12. Aryandono T, Harijadi, and Soeripto et al. Survival from Operable Breast Cancer: Prognostic Factors in Yogyakarta, Indonesia. Asian Pacific J. Ca. P. 2006; 7: 2-15.

13. AL-Joudi FS, Iskandar ZA, Rusli J, et al. The expression of p53 in invasive ductal carcinoma of the breast: a study in the north-east states of Malaysia. M.J.M; 2008; 63(2): 300-528.(Abstract ).

14. Pich A, Margaria $E$, and Chiusa $L$, et al. Oncogenes and Male Breast Carcinoma: c-erbB-2 and p53 Coexpression Predicts a Poor Survival. J.C.O 2002; 18(16): 29482956.

15. Levesque M.A, Katsaros $\mathrm{D}, \mathrm{Yu} \mathrm{H}$, et al. Immuonhistochemicaly determined p53 accumolation as a prognostic indicator in Italian breast cancer patients. Int. J. Ca. (Pred. Oncol.)1998;79:147-152.

16. Mhjoub $S$, zahreaei $M$, karami $F$, et al. Overexpression of p53 protien in malignant breast tumor: an immunohistochemical study. Acta medica Iranica 1999; 37:1-15.

17. Sa Y, cho S.H, Kim S.S, et al. overexpression of p53 as prognosic marker in breast cancer; Euro. J Ca. 1998; 55: 5-25.

18. Caleffi M, Tague MW, Jensen RA, et al. P53 gene mutations and steroid receptor status in breast cancer; Cancer. 1994; 73:2147-2159.

19. Mazars $R$, pinardi $L$, encheikh $M$, et al. P53 mutations occur in aggressive breast cancer .Ca. Res .1992; 52:3918-3923.

20. Uchikawa T. The relationship between p53, c-myc product expression and clinicopathological parameters in primary breast carcinomas. Acta Med. Nagasaki 1994; 39:198-203.

21. Bartley A, MBS, Ross D.W, et al. Validation of p53 Immunohistochemistry as a Prognostic Factor in Breast Cancer in 
Clinical Practice. Archives of Patho. and Lab. Med; 2001;126(4):456-458.

22. Orucevic A, Reddy V.B, Bloom K.J, et al. Predictors of Lymph Node Metastasis in T1 Breast Carcinoma, Stratified by Patient age. Breast. J. 2002; 8(6):349-355.

23. Lacroix M, Toillon R.A and Leclercq G, et al. P53 and breast cancer, an update. Endo.Related Ca 2006;13(2): 293-325.
24. Mourão Netto M , Logullo A.F, Nonogaki, et al. Expression of c-erbB-2, p53 and cmyc proteins in male breast carcinoma. Comparison with traditional prognostic factors and survival. Braz J. Med. Biol. Res. 2001; 34(7) :887-894. 